\title{
ERRATA
}

\section{Transformation of Tetrachloromethane to Dichloromethane and Carbon Dioxide by Acetobacterium woodii}

CHRISTINE EGLI, THOMAS TSCHAN, RUDOLF SCHOLTZ, ALASDAIR M. COOK, AND THOMAS LEISINGER

Department of Microbiology, Swiss Federal Institute of Technology, ETH-Zentrum, CH-8092 Zurich. Switzerland

Volume 54 , no. 11, p. 2822, Table 1, footnote $c$ : "autoclaved cultures" should read " $20 \%$ (vol/vol) $\mathrm{O}_{2}$ in the gas phase."

\section{Threshold Acetate Concentrations for Acetate Catabolism by Aceticlastic Methanogenic Bacteria}

PETER WESTERMANN, BIRGITTE K. AHRING, AND ROBERT A. MAH

Division of Environmental and Occupational Health Sciences, School of Public Health, University of California, Los Angeles, California 90024

Volume 55, no. 2, p. 514, column 2, line 39: "millimolar" should read "micromolar." 